\title{
Divergent effects of epidermal growth factor and calcipotriol on human rectal cell proliferation
}

\author{
M G Thomas, G R Brown, M R Alison, R C N Williamson
}

\begin{abstract}
Vitamin D may protect against colorectal cancer by reducing cell proliferation and inducing differentiation. By contrast, epidermal growth factor (EGF) stimulates cell proliferation and may encourage gastrointestinal mucosal healing. This study investigated the effect of a synthetic vitamin $D$ analogue, calcipotriol, and EGF on human rectal epithelial cell proliferation in patients with familial adenomatous polyposis (FAP). In addition, a new technique to measure the cell cycle time is described. Sigmoidoscopic biopsy specimens were obtained from 14 patients with FAP. Tissue was established in organ culture, with or without the addition of EGF $(n=8)$, or calcipotriol $(n=6)$. Proliferation was determined using (a) metaphase arrest to measure the crypt cell production rate, (b) native mitotic index, and (c) the growth fraction using PC10 antibody. EGF receptor expression was shown using a polyclonal antibody AP12E. Calcipotriol reduced crypt cell production rate by $52 \%$ from mean (SEM) $5.29(1.18)$ to $2.56(0.80)$ cells/crypt/hour $(p<0.01)$ and EGF increased crypt cell production rate by $102 \%$ from $3.62(0.59)$ to $7.33(0.90)$ cells/crypt/hour $(p<0.05)$, and this tissue expressed the EGF receptor. The growth fraction was $\mathbf{4 8 . 4 0}$ $(4.0) \%$, and the native mitotic index 1.08 $(0 \cdot 14) \%$. The cell cycle time was estimated as 94.5 hours and the time for mitosis as one hour. Thus, calcipotriol and EGF have divergent effects on human rectal mucosal proliferation.

(Gut 1994; 35: 1742-1746)
\end{abstract}

Familial adenomatous polyposis (FAP) has a well recognised genetic basis, which is characterised by the development of numerous adenomas throughout the gastrointestinal tract. ${ }^{1-3}$ There may also be a hereditary component to the adenomas that occur in family cancer syndrome patients, as well as many cases of sporadic adenomas. ${ }^{4-6}$ Mutations of the adenomatous polyposis coli (APC) gene are known to cause familial adenomatous polyposis ${ }^{7}$ and the MCC (mutated in colon cancer) gene is mutated and deleted in sporadic colon cancers. ${ }^{8}$ Indeed, the protein structures of the gene products of the MCC and APC gene are thought to be similar. ${ }^{9}$ These findings, together with the increasing acceptance of the adenomacarcinoma sequence, suggest that patients with FAP are good models for the development of colorectal cancer in humans. ${ }^{10-12}$ Epithelial hyperplasia in the large bowel precedes the development of colorectal cancer in many circumstances $^{13-15}$ and is associated with an increased rectal crypt cell production rate in humans. ${ }^{16-18}$

We have previously shown that both calcium and the active metabolite of vitamin $\mathrm{D}_{3}, 1,25(\mathrm{OH})_{2} \mathrm{D}_{3},{ }^{19}$ reduce rectal crypt cell production rate in biopsy specimens taken from patients with FAP. ${ }^{20}$ The potential therapeutic use of vitamin $\mathrm{D}$ is limited by its profound metabolic effects. A synthetic vitamin D analogue calcipotriol (MC-903) retains potent cell regulatory properties while having limited effects on calcium metabolism. ${ }^{21-24}$ Indeed, we have previously shown that calcipotriol can reduce in vitro crypt cell production rate by about $50 \%$ in tissue taken from normal controls. ${ }^{19}$ Synthetic vitamin $\mathrm{D}_{3}$ analogues with a similar ability to reduce cell proliferation might have a future therapeutic role to control disease in conditions characterised by a hyperproliferative colorectal epithelium.

Epidermal growth factor (EGF) accelerates epithelial proliferation in rat colon ${ }^{25} 26$ and may also stimulate gastrointestinal regeneration and ulcer healing. ${ }^{27-29}$ The EGF peptide binds to the extracellular domain of its receptor, ${ }^{30}$ and colorectal carcinoma cells express this receptor. ${ }^{31}$ Indeed, malignant colorectal cell lines can respond to EGF by increasing their rate of proliferation, and this may be an EGF stimulated autocrine effect. ${ }^{32} 33$

We have therefore compared the effect of calcipotriol and EGF on macroscopically normal rectal mucosa obtained from patients with FAP. We have used a stathmokinetic technique to determine crypt cell production rate and immunohistochemistry to estimate the cell cycle time.

\section{Methods}

CLINICAL MATERIAL

Paired rectal biopsy specimens were taken from 14 patients with FAP (mean age 42 years, range 29-65), who had previously undergone total abdominal colectomy with ileorectal anastomosis with a mean time from operation of 16 years (range 2-37). All patients were attending regularly for follow up. Specimens were taken between 0900 and 1200 during an outpatient visit. The patients were examined sigmoidoscopically, and a rectal biopsy specimen was obtained from an area of macroscopically normal rectal mucosa. One specimen from each patient was examined \\ Departments of \\ and Histopathology, \\ Royal Postgraduat
Medical School \\ Hospital, Londo \\ Hospital, L
G R Brown \\ 23 March 1994
}


histologically to exclude the presence of microadenomas, and sections from this tissue were also used for immunohistochemical analysis. The other sample was divided into small pieces, and these explants were used in the organ culture studies. The rectal tissue was cultured with either EGF $10 \mathrm{ng} / \mathrm{ml}(\mathrm{n}=8)$ or calcipotriol $1 \times 10^{-6} M(n=6)$.

\section{CHEMICALS}

The synthetic vitamin $\mathrm{D}$ analogue calcipotriol (MC-903 in isopropyl alcohol, Leo Pharmaceutical, Ballerup, Denmark) was added to culture medium to produce a stock solution with a final concentration of $1 \times 10^{-6}$ M MC-903 and was stored at $20^{\circ} \mathrm{C}$ until use. The control medium was prepared with a similar dilution of alcohol.

Mouse salivary gland epidermal growth factor (Sigma, Poole, UK) was added to organ culture medium to produce a stock solution containing $10 \mathrm{ng} / \mathrm{ml}$ of the peptide.

Proliferating cell nuclear antigen, which is expressed by all cells within the proliferative compartment of normal gastrointestinal tissue, was labelled using PC10, a monoclonal antibody directed against proliferating cell nuclear antigen (supplied by Professor David Lane, University of Dundee). AP12E, a rabbit polyclonal antibody directed against EGF receptor, was supplied by Dr W Gullick, RPMS, London.

\section{ORGAN CULTURE AND CRYPT CELL}

PRODUCTION RATE

Rectal crypt cell production rate was determined by a previously reported and validated technique. ${ }^{161920}$ Briefly, rectal explants were orientated on metal grids within an organ culture dish. In paired studies, the tissue was cultured with or without the addition of either calcipotriol $(n=6)$ or EGF $(n=8)$. Thus, each patient's tissue acted as its own control. After 15 hours of culture, vincristine $0.6 \mu \mathrm{g} / \mathrm{ml}$ (Oncovin, Eli Lily, Basingstoke, UK) was added to the culture medium to induce metaphase arrest within rectal crypts. Explants were then removed one, two, and three hours later. Crypt cell production rate was determined after microdissection of at least 20 crypts by plotting the mean number of arrested metaphases per crypt against the time from vincristine administration. ${ }^{34}$ The slope of this line, determined by least squares linear regression analysis, gave a value for the crypt cell production rate in cells/crypt/ hour. ${ }^{161920}$. Crypt cell production rate values were compared using a paired Student's $t$ test.

\section{MITOTIC INDEX}

Tissue from six patients was immediately fixed in Carnoy's fluid and stored in $70 \%$ alcohol. Later, the tissue was rehydrated using serial dilutions of alcohol and was then acid hydrolysed with $1 \mathrm{M} \mathrm{HCl}$ for six minutes to $60^{\circ} \mathrm{C}$. After staining with Schiff's reagent, the crypts were microdissected and viewed using oil immersion microscopy. The total number of cells was counted in at least 10 crypts, and the mean number of metaphases was counted in at least 20 crypts per specimen to determine the mean native mitotic index $\left(I_{m}\right)$ expressed as mitoses $/ 1000$ cells.

\section{IMMUNOHISTOCHEMISTRY}

\section{EGF receptor}

To discover if the EGF receptor was expressed in the tissue from the eight patients used to study the effects of EGF, control tissue that is, tissue not used in the organ culture experiments - was stained with the AP12E polyclonal antibody using an immunoperoxidase method. Immunohistochemical staining was performed on $3 \mu \mathrm{m}$ thick sections dewaxed in xylene and passed through serial dilutions of alcohol. Endogenous peroxidase activity was blocked with $0.3 \% \quad \mathrm{H}_{2} \mathrm{O}_{2}$ in phosphate buffered saline for 30 minutes. Three sets of slides were then prepared, one test and two control slides. To the first slide anti-EGF receptor rabbit polyclonal antibody (AP12E) was added (170 $\mu \mathrm{g} / \mathrm{ml}$ diluted 1:40), to the second slide TRIS buffer was added instead of the primary antibody, and to the third slide the antibody and the free peptide were added $(4 \mu \mathrm{g} / \mathrm{ml}$ anti-EGF receptor with $10 \mathrm{ng} / \mathrm{ml}$ free peptide). The TRIS buffer and free peptide slides were used as negative controls. Slides were left for one hour and then washed three times with TRIS buffer. A second layer consisting of biotinylated swine antirabbit IgG (1:300 in TRIS buffer) was applied for a period of one hour. After rinsing the slides three times in TRIS buffer, a third layer consisting of a peroxidase conjugated avidin-biotin complex (ABC, Dakopatts, UK), was applied for 45 minutes. The slides were again rinsed three times in TRIS buffer. Lastly, diaminobenzidine solution $250 \mu \mathrm{g}$ with $0.037 \% \mathrm{H}_{2} \mathrm{O}_{2}$ (to show peroxidase activity) was applied for five minutes, before slides were washed in tap water and counterstained with haematoxylin. 3536

\section{Proliferating cell nuclear antigen}

As a further index of cell proliferation, tissue expression of proliferating cell nuclear antigen was sought using the monoclonal antibody PC10. Tissue from the six patients used to determine the mitotic index was fixed in formalin and processed with 24 hours for optimal demonstration of proliferating cell nuclear antigen. Sections $(3 \mu \mathrm{m})$ were cut, air dried at room temperature, dewaxed, and taken through serial solutions of alcohol. Endogenous peroxidase was blocked as described above, and the sections were incubated for two hours at room temperature in a 1:20 dilution of the PC10 monoclonal antibody. Visualisation was performed using a similar method as described above; diaminobenzidine- $\mathrm{H}_{2} \mathrm{O}_{2}$ was used as the chromagen and Cole's haematoxylin as the counterstain. The labelling index was determined by the 


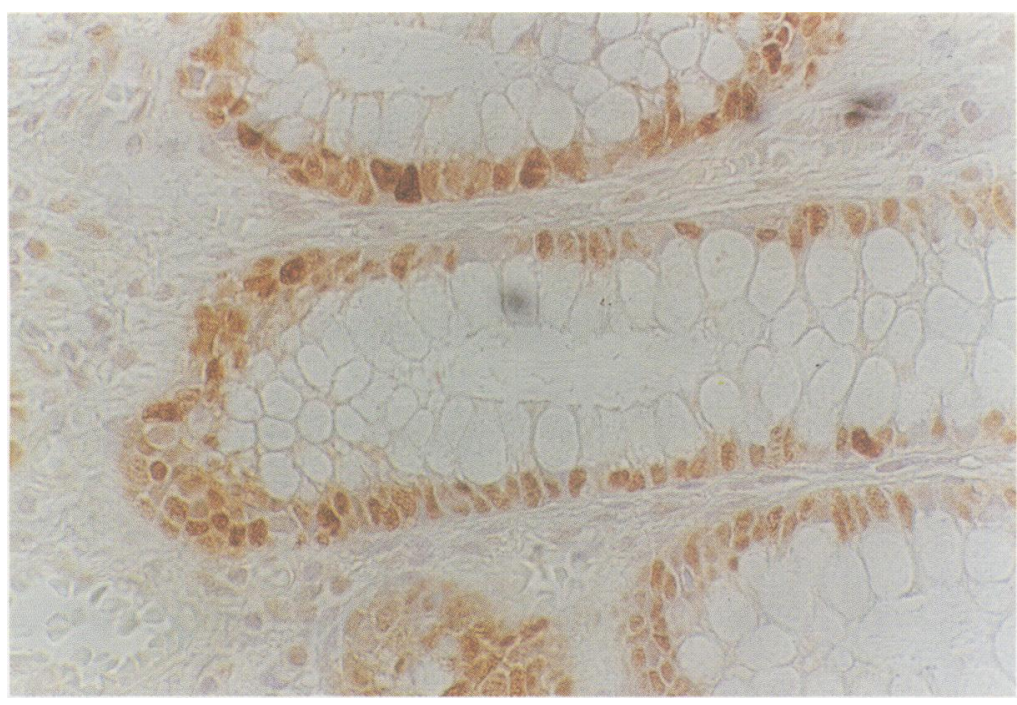

Figure 1: Immunohistochemical localisation of proliferating cells in FAP tissue using PC10 monoclonal antibody directed against proliferating cell nuclear antigen.

ratio of the number of labelled cells to the total number of cells within a crypt. The mean labelling index was determined from at least 10 crypts per section. ${ }^{37}$

\section{Results}

MITOTIC INDEX

Counting at least 10 crypts per biopsy specimen from six patients, the mean (SEM) number of cells/crypt was 1034 (48.75) and the native mitotic index was $10.82(1.40)$ cells $/ 1000$ cells $(1.08(0.14) \%)$. The mean crypt cell production rate in the same six patients was $5.29(1.18)$ cells/crypt/hour (range 1.55-11.09). Using this figure, a value for the birth rate of cells $\left(K_{\mathrm{b}}\right)$ can be calculated as 5.12 cells $/ 1000$ cells/hour - that is, $4 \cdot 61 / 1034 \times 1000$.

\section{PROLIFERATING CELL NUCLEAR ANTIGEN}

Strong staining with the PC10 antibody was seen in histological sections from all six patients used to determine the mitotic index (Fig 1). The zone of proliferation extended from the crypt base to a point just over halfway up the crypt. To calculate the labelling index

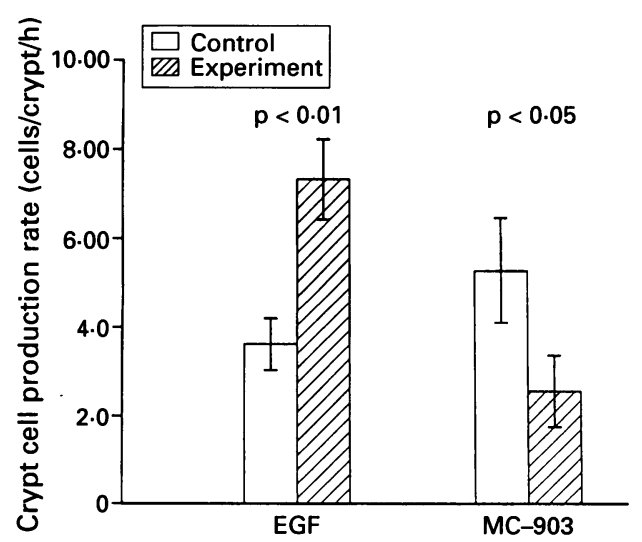

Figure 2: The effect of epidermal growth factor (EGF) and calcipotriol (MC-903) on human rectal crypt cell production rate in FAP. Values are mean (SEM). and hence an approximation to the size of the proliferative compartment, clearly stained cells were counted. The mean (SEM) labelling index was $484(40) / 1000$ cells $(48 \cdot 4(4 \cdot 0) \%)$. Using this labelling index as an approximation of the growth fraction $\left(I_{p}\right)$, then the cell cycle time $\left(t_{c}\right)$ can be calculated ${ }^{38}$ from the equation $t_{c}=I_{p} / K_{b}$, giving a value of 94.5 hours. In addition, the mean duration of mitosis $\left(t_{m}\right)^{38}$ can be determined from the equation $t_{m}=I_{p} / K_{b} \cdot I_{m}$, giving a value of 1.02 hours or 60 minutes.

CRYPT CELL PRODUCTION RATE (Fig 2)

The explants showed excellent preservation of tissue architecture after 18 hours of organ culture. The median control metaphase count was 11.72 cells/crypt (range $4 \cdot 16-18 \cdot 70$ ) at one hour, 14.36 cells/crypt (range $5 \cdot 11-33 \cdot 46$ ) at two hours, and $17 \cdot 42$ cells/crypt $(13 \cdot 22-35 \cdot 87)$ at three hours. Epidermal growth factor $(10 \mathrm{ng} / \mathrm{ml})$ increased mean (SEM) rectal crypt cell production rate by $102 \%$ in paired biopsy specimens from 3.62 $(0.59)$ to $7.33(0.90)$ cells/crypt/hour $(n=8$, $\mathrm{p}<0.01)$. Calcipotriol $\left(1 \times 10^{-6} \mathrm{M}\right)$ reduced mean rectal crypt cell production rate by $52 \%$ in paired specimens from $5.29(1.18)$ to 2.56 $(0.80)$ cells/crypt/hour $(n=6, p<0.05)$. There was no significant difference between the post MC-903 crypt cell production rate value and the control crypt cell production rate value in the EGF group, and this might reflect the wide variation seen in the overall control crypt cell production rate values (range 1.55-11.09 cells/crypt/hour).

\section{EGF RECEPTOR}

Expression of the EGF receptor was seen in sections of control tissue taken from all eight patients who showed an increased crypt cell production rate with EGF in organ culture (Fig 3). EGF receptor expression occurred above the crypt base and increased in intensity further up the crypt to well above the mid-zone of the crypt. No expression was seen in any of the immunohistochemical negative controls.

\section{Discussion}

The active metabolite of vitamin $\mathrm{D}(1,25$ $(\mathrm{OH})_{2} \mathrm{D}_{3}$ ) has an inhibitory effect on in vitro cell proliferation (crypt cell production rate) in rectal tissue from patients with FAP. ${ }^{19}$ We have now shown that a synthetic analogue calcipotriol (with limited hypercalcaemic effects) produces a similar reduction of rectal crypt cell production rate in FAP tissue. If this effect could be reproduced in vivo, then vitamin $\mathrm{D}$ synthetic analogues might have a therapeutic role to control exuberant mucosal proliferation in the rectal stump of FAP patients. Although topical calcipotriol has a dramatic effect in psoriasis vulgaris, ${ }^{22-24}$ it has a very short half life and it is not available for enteric use. ${ }^{21}$ In conditions that are associated with an increased risk from colorectal cancer, such as ulcerative proctocolitis, there is a 


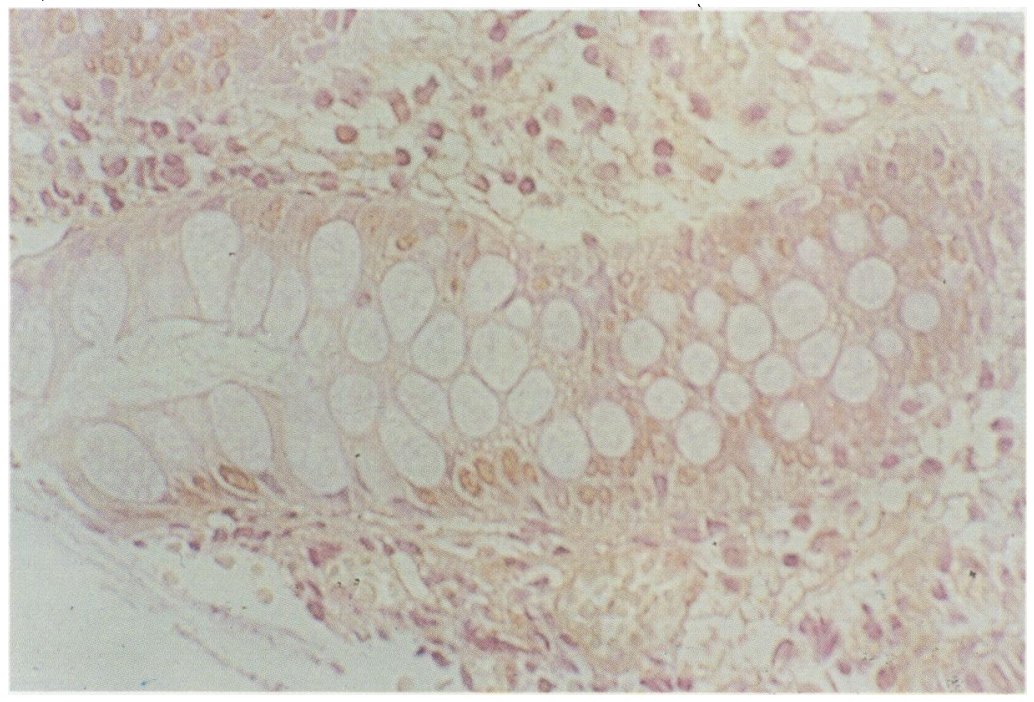

Figure 3: EGF receptor expression shown using the AP12E polyclonal antibody in a rectal crypt in tissue from a patient with FAP.

well reported increase in colorectal epithelial proliferation that persists even in quiescent disease. ${ }^{16} \mathrm{~A}$ similar dampening of colorectal epithelial proliferation might be beneficial in this inflammatory condition.

In addition to inhibition of proliferation, we have shown an ability to stimulate epithelial cell proliferation in FAP tissue using this in vitro technique. For the first time we have shown that epidermal growth factor can increase crypt cell production rate in human colorectal mucosa maintained in short term organ culture. We have also shown the expression of EGF receptor in control mucosal tissue from these patients. These findings correlate well with previously reported effects of EGF on the colorectum. ${ }^{25}{ }^{26}$ As both sides of the biopsy specimen were bathed in culture medium, it cannot be determined whether this is a luminal or a humoral action of the peptide. The increased crypt cell production rate seen may be similar to the phenomena reported by Wright et al. ${ }^{27} 28$ Alternatively, it may represent an action of the peptide on an abnormal expression of EGF receptor in patients with FAP. We have not studied the effect of EGF on in vitro crypt cell production rate in tissue taken from normal controls and indeed, such a study could aid the interpretation of our results.

Using immunohistochemistry (PC10) in combination with static and dynamic parameters of cell proliferation ( $I_{m}$ and crypt cell production rate), we can estimate the time spent in various phases of the cell cycle. Proliferating cell nuclear antigen can be labelled with the PC10 antibody in formalin fixed paraffin wax embedded tissue. ${ }^{37} 39$ This antibody shows a higher labelling index when compared with the exclusive $S$ phase marker bromodeoxyuridine, ${ }^{37}$ and therefore it may give approximate figures for the growth fraction that are similar to previous published estimates ${ }^{40}$ and it seems to be a reproducible and quantifiable marker of cell proliferation. ${ }^{37}$ Because FAP tissue stains strongly with the PC10 antibody, proliferating cell nuclear antigen labelling can readily estimate the growth fraction. If the cell birth rate is also known, the two figures can be used to estimate the cell cycle time. Our figure of about 95 hours is rather longer than estimates using thymidine labelling, which vary from 24-48 hours in colorectal cancers ${ }^{38} 4041$ to 32 hours in patients with adenomas ${ }^{42}$ and 72-96 hours in the normal colon and rectum. ${ }^{38} 43$ Our estimates must, however, be viewed as provisional until validated by more standard methods of determining cell cycle times such as thymidine labelling. In addition, direct comparisons with previously reported values are not appropriate because our patients had previously undergone total colectomy. Also, PC10 may overestimate the growth fraction because of its long half life. 373944 Nevertheless, the combination of immunohistochemistry with static mitotic and dynamic metaphase counting might in the future give useful kinetic information about the gastrointestinal epithelium in disease states.

The authors wish to thank The Polyposis Registry at St Mark's Hospital for their help. Financial assistance for this work was provided by the Nutritional Consultative Panel.

1 Herrera L, Kakati S, Gibas L, Pietrazak E, Sandberg AA. Brief clinical report: Gardner's syndrome in a man with interstitial deletion of $5 \mathrm{q}$. Am $\mathcal{J}$ Med Genet 1986; 25: 473-6.

2 Bodmer WF, Bailey CJ, Bodmer J, Bussey HJR, Ellis A, Gorman $\mathrm{P}$, et al. Localization of the gene for familial adenomatous polyposis on chromosone 5 . Nature 1987; 328: 614-6.

3 Leppert $M$, Dobbs $M$, Scrambler $P$, O'Connel $P$ Nakamura $Y$, Stauffer $D$, et al. The gene for familial polyposis coli maps to the long arm of chromosone 5 . polyposis coli maps to the
Science $1987 ; 238: 1411-3$.

4 Lynch HT, Smyrk T, Lanspa SJ, Marcus JN, Kreiger M, Lynch JF, et al. Flat adenomas in a colon cancer-prone kindred. $\mathcal{f}$ Natl Cancer Inst 1988; 80: 278-82.

5 Burt RW, Bishop DT, Cannon LA, Dowdle MA, Lee RE, Skolinick MH. Dominant inheritence of adenomatous colonic polyps and colorectal cancer. N Engl ₹ Med 1985; 312: $1540-4$.

6 Cannon-Albright LA, Skolnick MH, Bishop T, Lee RG, Burt RW. Common inheritence of susceptibility to colonic adenomatous polyps and associated colorectal colonic adenomatous polyps and associt

7 Nishisho I, Nakamura Y, Miyoshi Y, Miki Y, Ando H, Horii A, et al. Mutations of chromosone $5 \mathrm{q} 21$ genes in FAP and A, et al. Mutations of chromosone 5q 21 genes in FAP
colorectal cancer patients. Science 1991; 253: 665-9.

8 Kinzler KW, Nilbert MC, Volgestein B, Bryan TM, Levy $\mathrm{DB}$, Smith $\mathrm{KJ}$, et al. Identification of a gene located at chromosone $5 \mathrm{q} 21$ that is mutated in colorectal cancer. Science 1991; 251: 1366-70.

9 Groden J, Thliveris A, Samowitz W, Carlson M, Gelbert L, Albertsen $\mathrm{H}$, et al. Identification and characterisation of the familial adenomatous polyposis gene. Cell 1991; 66: 589-600.

10 Hill MJ, Morson BC, Bussey HJR. Aetiology of the adenoma-carcinoma sequence in the bowl. Lancet 1978; $\mathrm{i}$ : $245-7$.

11 Morson BC, Bussey HJR, Day DW, Hill MJ. Adenomas of the large bowel. Cancer Surv 1983; 2: 451-77.

12 Boman BM, Levin B. Familial polyposis. Hosp Pract 1986; 21: $155-70$.

13 Lipkin $M$, Newmark $H$. Effect of added dietary calcium on colon epithelial cell proliferation in subjects at high risk for familial colonic cancer. $N$ Engl $\mathcal{f}$ Med 1985; 313: 1381-4.

14 Lipkin $M$. Biomarkers of increased susceptibility to gastrointestinal cancer: new applications of studies of cancer prevention in human subjects. Cancer Res 1988; 48: $235-45$.

15 Terpstra OT, Van Blankenstein M, Dees J, Eilers GAM. Abnormal patterns of cell proliferation in the entire colonic mucosa of patients with adenoma or cancer. Gastroenterology 1987;92: 704-8.

16 Allan A, Bristol JB, Williamson RCN. Crypt cell production rate in ulcerative proctocolitis: differential increments in rate in ulcerative proctocolitis: differential in
remission and relapse. Gut 1988; 29: $1544-8$.

17 Appleton GVN, Wheeler EE, Al-Mufti R, Challacombe DN, Williamson RCN. Rectal hyperplasia after jejunoileal bypass for morbid obesity. Gut 1988; 29: 1544-58.

18 Barsoum GH, Hendricks C, Winslet MC, Donavan IA Neoptolemos JP, Keighley MRB. Reduction of mucosal crypt cell proliferation in patients with colorectal adenomatous polyps by dietary calcium. Br $\mathcal{f}$ Surg 1992; 79: 581-3. 
19 Thomas MG, Tebbutt S, Williamson RCN. Vitamin D and its metabolites inhibit cell proliferation in human rectal mucosa and a colon cancer cell line. Gut 1992; 33: 1660-3.

20 Thomas MG, Thomson JPS, Williamson RCN. Oral calcium inhibits rectal epithelial proliferation in familial adenomatous polyposis. Br f Surg 1993; 80: 499-501.

21 Binderup L, Bramm E. Effects of a novel vitamin D analogue MC-903 on cell proliferation and differentiation invitro and on calcium metabolism in-vivo. Biochem vitro and on calcium me

22 Kragballe K, Beck HI, Sogaard H. Improvement of psoriasis by topical vitamin $\mathrm{D}_{3}$ analogue (MC 903) in a double-blind study. Br F Dermatol 1988; 119: 223-30.

23 Kragballe $K$. Treatment of psoriasis by the application of the novel cholecalciferol analogue calcipotriol (MC 903). Arch Dermatol 1989; 125: 1647-52.

24 Kragballe K, Gjertsen BT, Hoop D, Karlsmark T, Van de Kerkhof PCM, Larko O, et al. Double-blind, right/left comparison of calcipotriol and betamethasone valerate in treatment of psoriasis vulgaris. Lancet 1991; 337: 193-6.

25 Goodlad R, Wilson TJG, Lenton W, Gregory $H$, McCullagh KG, Wright NA. Intravenous but not intragastric urogastrone-EGF is trophic to the intestine of parenterally fed rats. Gut 1987; 28: 573-82.

26 Reeves JR, Richards RC, Cooke T. The effect of intracolonic EGF on mucosal growth and experimental

27 Wright NA, Pike CM, Elia G. Ulceration induces a novel epidermal growth factor-secreting cell lineage in human gastrointestinal mucosa. Digestion 1990; 46 (suppl 2): 125-33.

28 Wright NA, Pike C, Elia G. Induction of a novel epidermal growth factor-secreting cell lineage by mucosal ulceration in human gastrointestinal stem cells. Nature 1990; 343: $82-5$.

29 Konturek PK, Brozozowski T, Konturek SJ, Dembinski A. Role of epidermal growth factor, prostaglandin and sulfhydryls in stress-induced gastric lesions.

30 Carpenter G. The biochemistry and physiology of the receptor kinase for epidermal growth factor. Mol Cell Endocrinol 1983; 31: 1-19.

31 Bradley S, Weiss MJ, Salem RR. Increased expression of EGF receptor on human colon carcinoma cells. Arch Surg 1986; 121: 1242 .
32 Anzano MA, Rieman D, Prichett W, Bowen-Pope DF, Greig R. Growth factor production by human colon carcinoma cell lines. Cancer Res 1989; 49: 2898-904.

33 Huang S, Lin PF, Fan D, Price JE, Trujillo JM, Chakrabarty SJ. Growth modulation by epidermal growth factor (EGF) in human colonic carcinoma cells: constitufive expression of the human EGF gene. $\mathcal{f}$ Cell Physiol tive expression of

34 Ferguson A, Sutherland A, MacDonald TT, Allan F. Technique for microdissection and measurement in biopsies of human small intestine. F Clin Pathol 1977; 30: 1068-73

35 Berger MS, Gullick WJ, Greenfield, Evans S, Addis BJ, Waterfield MD. Epidermal growth factor receptors in lung tumours. $\mathcal{f}$ Pathol 1987; 152: 297-307.

36 Gullick WJ, Hughes CM, Mellon K, Neal DE, Lemoine NR. Immunohistochemical detection of the epidermal growth factor receptor in paraffin-embedded human tissues. F Pathol 1991; 164: 285-9.

37 Sarraf CE, McCormick CSF, Brown G, Price YE, Hall PA, Lane DP, et al. Proliferating cell nuclear antigen immunolocalization in gastrointestinal epithelia. Digestion 1991; 50: 85-91.

38 Wright NA, Alison MR. The biology of epithelial cell populations. Vol 1 and 2. Oxford: Clarendon, 1984

39 Hall PA, Levison DA, Woods AL, Yu CC-W, Kellock DB, Watkins JA, et al. Proliferating cell nuclear antigen PCNA) immunolocalization in paraffin sections: an index of cell proliferation with evidence of deregulated expression in some neoplasms. F Pathol 1990; 162: 285-94.

40 Lipkin M, Bell B, Sherlock P. Cell proliferation kinetics in the gastrointestinal tract of man. I. Cell renewal in colon and rectum. 7 Clin Invest 1963; 42: 767-76.

41 Lipkin M. Cell cycle and cancer. New York: Decker, 1971: $1-26$.

42 Bleiberg H, Mainguet $P$, Galand P. Cell renewal in familial polyposis: comparison between polyps and adjacent healthy mucosa. Gastroenterology 1972; 63: 240-5.

43 Lipkin M, Sherlock P, Bell BM. Generation time of epithelial cells in the human colon. Nature 1962; 195: $175-7$.

44 Scott RJ, Hall PA, Haldane JS, Van Noorden S, Price Y, Lane DP, et al. A comparison of immunohistochemical markers of cell proliferation with experimentally determined growth fraction. $\mathcal{F}$ Pathol 1991; 165: 173-8. 